\title{
A "Era Lula", as eleições presidenciais de 2010 e os desafios do pós-neoliberalismo
}

Alexandre Fortes e John French

Em 2007, durante a Segunda Conferência Nacional de Políticas Públicas para as Mulheres, 2300 ativistas ouviram o ex-metalúrgico Lula - já então consagrado como o presidente de maior popularidade na história do Brasil - declarar que nenhum país poderia ser considerado "moderno e desenvolvido" se o crescimento econômico não beneficiasse "todos, sem exclusão e perpetuação de desigualdades históricas, sem preconceito de gênero, raça ou de qualquer outro". Seu discurso foi interrompido por uma explosão de aplausos e gritos de aprovação quando ele indicou que poderia apoiar uma mulher como sua sucessora (cf. Silva, 2007), o que se concretizou em 2010 com a eleição de Dilma Rousseff - uma guerrilheira transformada em tecnocrata que jamais havia concorrido a qualquer cargo eletivo.

A eleição da primeira presidenta do Brasil dá continuidade à quebra de precedentes que caracterizou a ascensão do próprio Lula. Um improvável ocupante do palácio presidencial, ele frequentou a escola primária por apenas quatro anos e começou a trabalhar nas ruas com 11 anos de idade, e tanto as ocupaçóes manuais a que se dedicou como a sua origem regional o "escurecem" consideravelmente num país com uma poderosa hierarquia de classe racializada.

Seu segundo mandato foi corretamente avaliado como "muito mais confiante" pelo historiador marxista britânico Perry Anderson. Embora possa ser exagerado denominá-lo como uma "radicalização no governo" 
1. Menos ainda que ele conduziria essa economia rumo à sua transformação na sexta maior do mundo.
(Anderson, 2011, p. 3), há poucas dúvidas de que ele produziu resultados mais coerentes com sua convicção manifesta de que não é possível falar em "desenvolvimento" ou "crescimento econômico" sem distribuição de renda (apud Baer e Love, 2009, p. 236). A confluência de tendências econômicas favoráveis e iniciativas governamentais dignas de crédito levou Lula a desfrutar de níveis de popularidade pessoal extraordinários e contínuos, inicialmente entre $60 \%$ e $70 \%$, chegando a $80 \%$ às vésperas da vitória de Rousseff (cf. Silva et al. 2010, pp. 124-139). A declaração do candidato presidencial opositor, José Serra, de que "Lula está acima do bem e do mal" (Lacerda, 2010) e a afirmação tão simpática quanto jocosa do presidente norte-americano Barack Obama um ano antes ("Esse é o cara! [...] É o político mais popular do mundo" [Tapper, 2009]) ecoam as conclusões de Anderson: "Por qualquer critério, Luiz Inácio da Silva é o político mais bem-sucedido do seu tempo" (2009, p. 3). A oposição temeu que tamanha popularidade levasse o presidente a seguir o exemplo de seu antecessor, patrocinando a possibilidade de uma nova reeleição, mas na verdade ela viabilizou a jogada mais arriscada (e mais democrática) de eleger uma sucessora desconhecida do eleitorado.

Vitorioso em 2002, parecia pouco provável que o ex-líder grevista fizesse um bom trabalho dirigindo a décima maior economia do mundo ${ }^{1}$, já que sua única experiência executiva anterior tinha sido cinco anos à frente de um grande sindicato. Ele tinha exercido um único mandato de deputado federal, durante o qual não demonstrou nem brilho nem talento. Menos provável ainda era que ele pudesse administrar com sucesso um sistema político de notória complexidade e moral dúbia, com a esquerda minoritária nas duas casas do Congresso e controlando apenas uns poucos governos estaduais. Confrontado com uma situação macroeconômica em deterioração, seu primeiro mandato foi marcado por austeridade e ortodoxia, desapontando muitos na esquerda; um escândalo de corrupção em 2005 produziu grandes danos ao PT e marginalizou muitos dos seus líderes. A despeito dessas formidáveis dificuldades, Lula ganhou a reeleição em 2006, novamente com 61\% dos votos no segundo turno (cf. Hunter e Power, 2007, pp. 16-17).

Esse fenômeno tem dado origem a vários questionamentos. Em que medida a popularidade de Lula reflete realizações substantivas do seu governo? Seria ele um líder "personalista" cuja proeminência individual ameaça a institucionalidade democrática? O sucesso de Lula como presidente é uma realização a ser celebrada pela esquerda ou um desvio em relação a princípios ideológicos? O "petismo" degenerou num "populismo" e num 
amorfo culto à personalidade ("lulismo")? Lula e o PT ainda mantêm o seu éthos fundacional favorável à expansão da participação popular?

A eleição dos líderes da resistência antineoliberal à presidência de diversos países latino-americanos (cf. French, 2009, pp. 349-370) transcorre num contexto em que, como aponta Juarez Guimarães, muitos "fenômenos ainda não têm nomes próprios" e falta-nos "a gramática conceitual para expressá-los e uma narrativa clara com a qual nos orientar" (Guimarães, 2008). Enquanto muitos observadores insistem em ler o presente pelas lentes desencorajadoras do passado, os líderes dos principais partidos de esquerda da região, reunidos no Foro de São Paulo, manifestam a firme convicção de que estamos vivendo "não apenas uma época de mudanças, mas uma mudança de épocas" ("Declaración final”, 2008).

Essa é a trajetória que levou à consagração de Lula como símbolo de uma nova era marcada pela centralidade do combate à desigualdade social na agenda política brasileira, visando contribuir para o balanço dos avanços e dos desafios colocados para o pós-neoliberalismo em escala latino-americana e global ${ }^{2}$.

\section{2: o triunfo da política}

A maxidesvalorização de 1999, logo no começo do segundo mandato de Fernando Henrique Cardoso ${ }^{3}$, marcou o início da derrocada da legitimidade anteriormente conquistada pela coalizão PSDB-PFL perante a população brasileira, baseada no simbolismo do real como garantia de poder de compra estável. A partir daí, à medida que as condições sociais produzidas pelas políticas neoliberais se deterioravam, o número daqueles que declaravam intenção de voto em Lula crescia. Mas esse movimento não era "natural" ou "inevitável". Aproveitar a oportunidade representada pelo desgaste do governo FHC exigia a construção de uma alternativa política percebida pela maioria da população como adequada e viável.

Derrotado por Collor em 1989, Lula tomou a arriscada decisão de não concorrer a nenhum outro cargo que não fosse a presidência da República, e passou a cruzar o país de ponta a ponta com as "Caravanas da Cidadania”. Assim, adquiriu um incomparável conhecimento vivo da realidade que lhe proporcionaria integrar ao seu discurso político exemplos concretos e relevantes, qualquer que fosse o assunto em questão. Tornava-se assim um porta-voz político avalizado não apenas dos movimentos sociais organizados, mas de um espectro social muito mais amplo: de comunidades vivendo
2. Sobre o pós-neoliberalismo, ver Burdick et al. (2009) e Macdonald e Ruckert (2009).

3. Marcada por episódios nebulosos que acabariam resultando na prisão e condenaçāo do expresidente do Banco Central, Chico Lopes. 
na pobreza absoluta até setores empresariais prejudicados pelos efeitos do neoliberalismo. Também fundou o Instituto da Cidadania, um think tank para o debate e a produção de diretrizes para políticas públicas, autônomo em relação ao partido.

Desfrutando de uma ampla liberdade de movimentos em comparação com políticos eleitos, Lula se tornou um símbolo de preocupação com justiça social e, depois de fracassar três vezes na sua tentativa de chegar à presidência, também de perseverança. A diminuição de seus índices de rejeição, perceptível já no início de 2002, resultava de um processo de longo prazo que envolvia muito mais do que marketing. Na campanha presidencial vitoriosa, ao contrário da disputa para governador vinte anos antes, não era mais retratado como uma vítima do "sistema", injustamente preso, alguém "igualzinho a você". Era agora apresentado aos eleitores como um self-made man da política, realista e responsável, internacionalmente reconhecido, mas orgulhoso de suas origens. O drama de sua trajetória pessoal era utilizado para demonstrar que, a despeito das perversões do capitalismo nacional e das limitações da democracia no país, os brasileiros tinham muito de que se orgulhar e razões para manter a esperança em um futuro melhor, dotando de novos significados o antigo slogan "Sem medo de ser feliz".

Enquanto isso, experiências das administrações locais mostravam que o PT era capaz de gerar governos que reorientassem as políticas públicas em favor dos interesses das maiorias. A crença, algo ufanista, em um "modo petista de governar" completamente distinto do praticado por outros partidos ganhou aceitação porque estava enraizada em realizações concretas: práticas políticas que expandiram o acesso a educação, saúde e habitação, melhoraram a qualidade do serviço e dos bens públicos; programa de crédito popular e, acima de tudo, iniciativas objetivando elevar os níveis de participação popular, tais como o orçamento participativo. Marcas registradas dos governos locais petistas nos anos de 1990, essas políticas renderam não apenas altos índices de apoio popular, mas também um número desproporcionalmente elevado de prêmios nacionais e internacionais de "boa governança".

Assim, no começo do século XXI a imagem pública de Lula tornava-se mais positiva, enquanto a camada dirigente do PT estava se tornando mais pragmática e seus governos locais aprofundavam a capacidade de produzir inovação na gestão pública. Entretanto, a base original do PT, em termos das suas raízes nos movimentos sociais, defrontava-se com uma profunda crise. O tamanho, a composição e o poder de barganha de categorias como metalúrgicos e bancários, que haviam liderado o novo sindicalismo nos anos de 
1980, declinavam dramaticamente. A ideia de uma fábrica automobilística de 40 mil trabalhadores, como a planta da Volkswagen em São Bernardo do Campo na época do Lula sindicalista, pertencia agora a um passado remoto. Os efeitos combinados da estagnação econômica, do alto desemprego e da reestruturação produtiva colocavam o sindicalismo na defensiva. A situação era um pouco diferente no campo, onde os trabalhadores sem-terra (organizados no MST, dentre outros movimentos) expandiam suas ações e permaneciam bastante ativos, embora discordâncias políticas significativas tenham esfriado suas relações com o PT.

$\mathrm{Na}$ Igreja Católica, os grupos progressistas sofriam duros reveses nas mãos dos conservadores do Vaticano e começavam a perder apoio popular para o pentecostalismo e para o Movimento Carismático. Embora o PT sempre tenha sido crítico do "socialismo realmente existente", os intelectuais do partido foram profundamente afetados pela queda da União Soviética e dos regimes do Leste Europeu, e a crise da teoria socialista produzia um crescente gap entre as atividades políticas do dia a dia e a necessidade, vital para qualquer militância, de algum tipo de perspectiva utópica.

Assim, quando a estratégia eleitoral para as eleiçōes presidenciais de 2002 foi definida, o PT estava mais forte no campo institucional, mas mais fraco na sua base orgânica, cenário agravado pela "drenagem de cérebros" dos movimentos sociais para dentro da administração pública. O partido tinha sido capaz de se tornar um ator na política nacional, uma alternativa viável de poder, mas sabia que não poderia contar com uma nova onda de ativismo para impulsionar sua vitória na quarta tentativa de conquista da presidência da República. Era evidente que um arco de alianças mais amplo se tornava necessário, e o PT voltou-se ao pequeno Partido Liberal de centro-direita para obter o candidato à vice-presidência José Alencar. Proprietário da maior indústria têxtil do país, Alencar era um tipo mais tradicional de self-made man, mas se provaria útil para acalmar seus colegas homens de negócios e para atrair para Lula um grande número de votos no estado-chave de Minas Gerais, que o tinha elegido senador em 1998.

Durante a campanha de 2002, o PSDB governante e os operadores de mercado realizavam a sua própria profecia sobre os riscos de um ataque especulativo no caso da vitória de Lula. A resposta viria com a famosa "Carta ao Povo Brasileiro", que destacava que um "novo modelo não pode ser o produto de decisões unilaterais do governo" e que elas deveriam ser o "fruto de uma ampla negociação nacional, visando uma autêntica aliança em favor do país, um novo contrato social, capaz de assegurar crescimento 
com estabilidade". Lula se comprometeria com o respeito aos "contratos e obrigações do país" e com a manutenção do superávit primário nas finanças públicas "o quanto fosse necessário". A "Carta” expressava as diretrizes básicas que enquadrariam as políticas econômicas do início do governo Lula.

Embora o PT tenha ganhado a maior fatia individual de assentos na Câmara dos Deputados, mesmo uma vaga definição de "partidos progressistas" não chegaria a computar um terço dos deputados. A eleição gerou um aumento no número de senadores petistas (muitos deles mulheres), mas essa minoria de novatos não poderia competir em experiência e influência com os senadores de centro-direita, em geral ex-governadores e líderes de importantes oligarquias regionais. Assim, a construção de uma maioria parlamentar pelo governo Lula baseou-se num amplo e instável arco de alianças que, assim como a condução macroeconômica, lhe impôs profundas contradições.

Essas duras realidades do exercício do poder Executivo federal levavam muitos a apostar que a celebração popular que se seguiu à eleição de Lula acabaria inevitavelmente em frustração, previsão que pareceu muito próxima de se confirmar em 2004-2005. O presidente não cansou de expressar a consciência da pesada responsabilidade que pesava sobre os seus ombros. Em 2010, falando aos metalúrgicos, recordou: "Eu não podia fracassar. Se isso acontecesse nunca mais um trabalhador poderia pleitear a presidência, pois eles iriam dizer que peão da fábrica não sabe governar. Eu tinha que provar que nós poderíamos ser melhores que aqueles que governaram antes de nós" (Amaral, 2010). Mas o que definiria "fracasso"? E como se construiu o "sucesso"?

Em 2003, o então prefeito de Belo Horizonte (e atual ministro da Indústria e Comércio), Fernando Pimentel, resumiu o dilema enfrentado por Lula e pelo PT: "as diretrizes macroeconômicas atuais, consequência necessária das escolhas feitas pela sociedade brasileira nos anos 1990 [...], comprometem o grande objetivo nacional, que é alcançar rapidamente a plena inclusão social" (2004, p. 27). O amadurecimento do PT como alternativa de poder se deu em meio ao ciclo de ascensão e queda do apoio popular ao neoliberalismo no país durante os anos de 1990. Na campanha de 1989, Lula defendera a suspensão do pagamento da dívida externa como ponto de partida para um novo modelo econômico. A legitimidade do endividamento era questionada, entre outros motivos, pela sua expansão vertiginosa durante a ditadura militar, quando nenhum escrutínio público era possível. A campanha demonstrou o apelo popular de algumas das ideias-chave do discurso neoliberal. Mesmo um candidato formado na tradição nacional-desenvolvimentista, como Mário Covas, pautaria sua frustrada campanha pela defesa de um "choque de capitalismo", 
mas era em Fernando Collor de Mello que a maioria do eleitorado reconhecia a energia necessária à empreitada antiestatal.

Em 1994, com o país ainda enfrentando altas taxas de inflação, o governo interino de Itamar Franco adotou o Plano Real, de surpreendente eficácia e popularidade, que assegurou a derrota de Lula nas mãos do então ministro da Fazenda, Fernando Henrique Cardoso. A liderança do PT percebia cada vez mais que o apoio a medidas de estabilização econômica ortodoxa era mais amplo e mais profundo do que o partido acreditava até então. Afinal, planos econômicos heterodoxos adotados durante a "Nova República" iniciada em 1985 haviam fracassado sucessivamente, gerando inflação cada vez mais descontrolada, instabilidade econômica e desigualdade crescente. Para quem não possuía conta bancária ou salário formal, conhecer o poder de compra efetivo da sua remuneração do primeiro ao último dia do mês parecia compensar em muito os efeitos colaterais negativos do Plano Real. Se Lula quisesse ser eleito e governar, teria que provar que manteria (na verdade, em 2002, resgataria) tal estabilidade econômica, ao mesmo tempo em que buscaria ao menos mitigar o seu custo social enquanto criasse condições para a emergência de um novo modelo de desenvolvimento.

O PT não ignorava que as políticas econômicas domésticas feitas nos anos de 1990 eram definidas com escassa margem de manobra diante do cenário internacional, resultante do modo pelo qual os Estados Unidos reestruturaram sua hegemonia desde os anos de 1980. O partido continua a denunciar que as políticas ditadas pelas agências multilaterais aos países do Terceiro Mundo e a intensa pressão dos mercados internacionais eram parte da mesma globalização neoliberal. Sob Cardoso, somavam-se às restrições externas abusos domésticos, tais como a corrupção generalizada que marcou os processos de privatização e a compra de deputados a fim de assegurar a aprovação da emenda constitucional que permitia a reeleição do presidente em exercício. Fernando Henrique evitou o trágico destino da maioria dos promotores do neoliberalismo latino-americano nos anos de 1990, mas encolheu politicamente até atingir melancólicos 18\% de aprovação popular, tornando-se companhia política indesejável em 2002. Ainda assim, como Pimentel salientava, a rota seguida pelo país nos anos de 1990 resultara de escolhas democráticas.

\section{Os desafios de Lula em perspectiva histórica}

Vista da perspectiva do movimento operário e da esquerda, a eleição de Lula foi a realização eletrizante de um sonho longamente suprimido. A lide- 
rança do país tinha permanecido - da colônia à Independência, da escravidão à liberdade, da Monarquia à República - sempre nas mãos das classes dominantes e da minoria educada que servia aos seus interesses. O Brasil permanece profundamente marcado pelas poderosas tradiçóes autoritárias geradas por 350 anos de escravidão africana. A classe dominante do país foi incrivelmente bem-sucedida na proteção dos seus privilégios e da sua extraordinária riqueza, mantendo-o com a terceira pior colocação dentre 150 países no que diz respeito à distribuição de renda. Essa ausência de rupturas mantém atuais, em pleno começo do século XXI, as denúncias do abolicionista afrodescendente André Rebouças:

A extinção da escravidão elevou o problema da Abolição da Miséria ao primeiro plano. O escravagismo era uma grande máquina de produzir proletários e miseráveis. Foi ele quem tornou possível, durante três séculos, o monopólio territorial mais monstruoso que se há visto sobre a superfície do globo. Esse monopólio produziu a Miséria Urbana, sem chão, sem ar, sem luz, acumulada em pocilgas; mendigando durante o dia e dormindo à noite em monturos humanos, foi ele quem produziu a miséria rural, sem terra, sem salário, sem compensação alguma, sem a mínima ideia de justa e equitativa distribuição entre o capital e o trabalho (apud Santos, 1985, pp. 348-349).

Em 2002, pela primeira vez, o poder foi colocado nas mãos de um representante da maioria popular e de uma coalizão de centro-esquerda, multiclassista em natureza, mas sob a hegemonia de um partido de esquerda. A maioria da população tinha votado, pela primeira vez, em um homem de pouca educação formal, num país em que a deferência popular para com os superiores, especialmente os letrados (os doutores), era uma tradição profundamente arraigada, tanto nas cidades como no campo. A vitória de Lula continha todos os elementos para gerar impactos de longo prazo sobre

4. Esse balanço preliminar começou como um projeto interdisciplinário envolvendo quinze pesquisadores que se encontraram entre 2007 e 2009 e que incluía uma conferência internacional de pesquisa na Duke University, 27-28 de maio de 2008. Os resultados mais recentes foram apresentados de forma mais abrangente em French e Fortes (2012, pp. 7-28). a cultura política brasileira, particularmente no que diz respeito ao aumento da autoconfiança da classe trabalhadora e à sua crença na própria capacidade de produzir mudanças sociais significativas.

Porém, como apontávamos já em 2005 (cf. French e Fortes, 2005, p. 29) ${ }^{4}$, a chegada do Partido dos Trabalhadores à presidência do Brasil, sem nenhuma alteração substantiva num sistema político estabelecido para reproduzir profundas desigualdades, representava um grande paradoxo. Diante disso, argumentávamos que "a mudança sob o governo Lula não é e não será revolucionária”, já que ele não era um produto da insurgência 
de massas ou "um triunfo dos movimentos sociais", exceto em "um sentido limitado [como] um triunfo de uma notável geração de líderes que surgiram dos dinâmicos movimentos de protesto que puseram fim ao Regime Militar (1964-1985)" (Idem, pp. 24-25). Sua eleição, insistíamos, era acima de tudo um triunfo da política, com as suas forças e fraquezas, e a votação em massa obtida por Lula não poderia ser vista como um repúdio consciente do neoliberalismo (cf. Idem, ibidem).

Nossa abordagem cautelosa diferenciava-se abruptamente de uma ênfase unilateral nas continuidades, que permeava muitos dos debates políticos e acadêmicos ${ }^{5}$. Movendo-se tanto a partir do centro como da esquerda, os críticos do governo foram rápidos em invocar - às vezes de forma oportunista - sentimentos poderosos de traição, desapontamento e ilusões perdidas para estabelecer questôes provocativas, tais como se Lula e o PT ainda poderiam ser considerados "de esquerda" ${ }^{6}$. Mais frutífera, parece-nos, é a indagação lançada por Werner Baer e Joseph Love na introdução de sua coletânea lançada em 2009: "em que aspectos o governo Lula representa uma ruptura com o passado?” (p. 305) ${ }^{7}$. Como apontam os dois brasilianistas, "a participação política das classes baixas" é uma questão-chave para a compreensão das mudanças em curso no país precisamente pelo "primado da política na geração de redistribuição de renda” (Idem, p. 312).

Nesse sentido, compartilhamos o julgamento de Perry Anderson (2011, pp. 11-12) sobre a presidência de Lula: "Visto como um período da política econômica brasileira, ele pode ser encarado como contíguo ao de Cardoso, um desenvolvimento a partir da mesma matriz. Visto como processo social, por outro lado, ele marcou uma ruptura perceptível" com o passado do Brasil. Atento às ambíguas dinâmicas antropológicas da política eleitoral, Anderson aponta a colossal unicidade brasileira:

O peso bruto eleitoral dos pobres, contraposto ao peso bruto da desigualdade econômica, para não falar da injustiça política, faz do Brasil uma democracia distinta de qualquer sociedade no Norte, mesmo aquelas em que as tensões de classe tenham sido mais acentuadas ou o movimento operário mais forte. A contradição entre essas duas magnitudes mal começou a se processar (Idem, ibidem).

O Brasil vive atualmente o momento mais democrático da sua história, após seis eleições presidenciais consecutivas. Durante a República Populista (1945-1964), além dos efeitos negativos da criminalização generalizada da atuação da esquerda e dos movimentos sociais, que mencionamos ante-
5. Fortes (2009, pp. 109-125) oferece um balanço dos debates no interior da esquerda brasileira causados pelas frustraçōes, ansiedades e dilemas vinculados ao papel do PT no governo nacional ao longo das gestôes de Lula.

6. Para exemplos, ver Kingstone e Ponce (2010, pp. 98, 100, 122), Silva, Braga e Costa (2010, pp. 124, 136) e Hunter (2008, p. 16). Os estudos empíricos do posicionamento ideológico entre os legisladores nacionais brasileiros de 1990 a 2005 mostram um clássico alinhamento esquerdadireita, com uma moderada inflexão à direita em todos os partidos (cf. Power e Zucco Jr., 2009, pp. 219-220, 231-232).

7. Essa é a questão colocada na conclusão da coletânea organizada por Baer e Love (2009), de grande densidade empírica e bastante esclarecedora. 
8. Bethell e Nicolau (2008, p. 234) também notam que o Brasil foi o último país das Américas a conceder o direito de voto aos analfabetos. O número de analfabetos absolutos era de $11 \%$ em 2005, somando-se a $24 \%$ de analfabetos funcionais, definidos como aqueles com menos de quatro anos de escolaridade (cf. Monclaire, 2007, p. 19). Ver também Ekins (2000, p. 115).

9. Nas duas últimas eleições, os demais candidatos dignos de nota foram dissidentes petistas (Heloísa Helena e Cristovam Buarque em 2006; Marina Silva e Plínio de Arruda Sampaio em 2010). riormente, os analfabetos (51\% da população em 1950) eram excluídos do direito ao voto, e golpes militares eram cogitados cada vez que as características repressivas do sistema eram colocadas em xeque por conflitos sociais ou políticos. A Nova República brasileira estendeu o voto aos analfabetos (20-25\% da população adulta em 1988) ${ }^{8}$. Todos os partidos políticos têm operado na legalidade desde 1985. PT e PSDB, expressōes da capacidade de liderança nacional conquistada ao longo do processo de redemocratização por dois segmentos da sociedade paulista (sindicalistas do ABC e intelectualidade formada na USP) (cf. French, 2010, pp. 91-113), há vinte anos são os únicos partidos capazes de gerar candidatos presidenciais viáveis?

Algumas agremiações de porte médio tentam manter uma identidade e autonomia enquanto gravitam ao redor dos dois polos, num quadro complementado pelo PMDB, federação de máquinas políticas estaduais, massa amorfa sem qualquer identidade programática, e pelos chamados partidos "nanicos", majoritariamente de direita e centro-direita. Por um lado, essa delicada engenharia garante a estabilidade política do país, forjando um sistema com altíssima capacidade de acomodação de interesses diversos. Mas o seu custo vai além da corrupção endêmica que abastece as máquinas políticas e, em muitos casos, as fortunas pessoais construídas com o desvio de recursos públicos. A imperiosidade das negociaçôes com os "aliados" fisiológicos limita severamente a capacidade do exercício do governo numa linha programática coerente por parte dos partidos que protagonizam as disputas presidenciais. Esse quadro, apesar de estar longe do ideal, tem proporcionado condiçōes para melhoras graduais e cumulativas no que diz respeito à qualidade de vida dos setores menos favorecidos da população e à consolidação de um ambiente institucional democrático. Nos últimos anos, é possível apontar o amadurecimento de mecanismos de controle social que estabelecem limites e barreiras crescentes à impunidade e produzem certa depuração no próprio sistema. Mas a possibilidade de que a contradição entre essa crescente consciência cidadã e a base fisiológica da nossa estabilidade política promova um salto de qualidade nas regras do jogo político brasileiro parece, neste momento, bastante remota.

Há claras indicaçōes de que a estabilidade do sistema eleitoral e o progresso rumo a uma democracia mais inclusiva começam a produzir uma tendência a agendas políticas cumulativas. A expectativa popular é de que as realizaçôes de cada governo sejam levadas adiante pelo seguinte, acrescidas de atenção a preocupaçóes emergentes. Para se tornar presidente, Lula teve que convencer os eleitores de que se dedicaria à estabilidade econômica antes de 
obter seu apoio para o foco proposto de redução das desigualdades sociais. Essa combinação bem-sucedida sob Lula não apenas lhe garantiu altas taxas de aprovação, mas lhe deu capital político para eleger sua sucessora. Já em 2010, pela primeira vez a questão da sustentabilidade ambiental adquiriu proeminência no processo eleitoral presidencial, como indicam os quase $20 \%$ de votos dados no primeiro turno à ex-ministra do Meio Ambiente, Marina Silva.

\section{Lulismo mais petismo: autoestima popular e mobilização da sociedade civil}

Nas suas primeiras décadas de existência, o Partido dos Trabalhadores consolidou-se como uma organização política peculiar. Originário de movimentos de massas, seus dedicados militantes possuíam fortes laços com os setores organizados da sociedade civil. Antileninista e antisssocial-democrata, o partido mantinha uma forte identidade apesar do perfil ideológico plural, manifesto no direito a tendências. $\mathrm{O}$ processo democrático de tomada de decisões no PT chamava a atenção da esquerda internacional. Para muitos, era o arquetípico partido de massas moderno, uma antítese dos "partidos-ônibus" dominantes no Brasil. O PT é o único partido brasileiro com filiação maciça (entre 500 e 800 mil membros registrados em 2000) ${ }^{10}$, uma adesão bem estabelecida entre os eleitores (cf. Samuels, 2006, pp. 5-6; Singer, 2010, p. 91) e, dentre os grandes partidos, um grau comparativamente alto de coesão e organização interna. Destaca-se também em termos de adesão dos eleitores. Enquanto a maior parte do eleitorado não tem identificação partidária, um em cada quatro eleitores identifica-se com o PT, um índice que, mesmo com o chamado "escândalo do Mensalão", só temporariamente se reduziu a um em cada cinco. Os únicos outros partidos com um grau significativo de identificação por parte dos eleitores - o PSDB e o PMDB - são a preferência declarada de um a cada vinte eleitores (cf. Samuels, 2006, pp. 5-6; Singer, 2010, p. 91).

Mas por muito tempo um dos elementos-chave no sucesso do "petismo" permaneceu sem exame: a importância extraordinária do seu fundador, cujo apelo ia muito além do partido. A questão parecia estranha à cultura política de um partido "baseado em movimentos sociais", que se orgulhava de não ser “o veículo de um líder”, em contraste, por exemplo, com o PDT de Leonel Brizola. Com uma militância (ao contrário dos simpatizantes) fortemente composta por pessoas de classe média (cf. Samuels, 2006; César, 2002), não surpreende que o PT se considerasse fundamentalmente em termos de plataformas de campanha e definições programáticas. Mas as corridas presidenciais
10. A estimativa mais baixa para 2000 é de André Singer (2010, p. 92) e a mais alta, de David Samuels (2001, p. 1009$)$. 
mostravam uma realidade distinta. A votação dos candidatos a parlamentares do partido foi 35\% dos votos de Lula em 1994, subiu para 41\% em 1998 e 2002, caindo para 30\% em 2006 (cf. Zucco, 2008, p. 32).

Com o declínio dos movimentos de massas nos anos de 1990, o PT deu-se conta de que a história de vida, a personalidade e o inquestionável carisma de Lula guardavam as chaves para a conquista da presidência (cf. Barreira, 2002, p. 170). Uma vez alcançado esse objetivo, entretanto, a popularidade e a influência do presidente (lulismo) só viriam a crescer. Durante seu primeiro mandato, a distância entre as políticas de governo e o programa partidário tensionou as identidades petistas. Quando escândalos de corrupção em 2005 derrubaram líderes, deputados e ministros do PT, foi o continuado suporte de Lula entre a população que salvou o dia na eleição de 2006, uma vitória descrita como espantosa, enfática e esmagadora (cf. Hunter e Power, 2007, pp. 1, 2, 20, 24; Souza, 2011, p. 78), a partir da qual a discussão sobre o lulismo se intensificou.

Embora a margem da vitória tenha sido a mesma de 2002, o perfil do eleitorado alterou-se significativamente: "quanto maior a renda, menor a probabilidade de alguém votar” em Lula era a constatação que pela primeira vez ganhava corpo. Enquanto nas três eleições anteriores, um maior nível educacional aumentava as possibilidades de um indivíduo votar em Lula, em 2006 ele "perdeu terreno entre eleitores com educação superior" e experimentou seu "maior crescimento vindo de brasileiros com poucos anos de educação formal” (Bohn, 2011, pp. 66-68). Pesquisas de opinião registraram um apoio desproporcional a Lula entre os eleitores autoidentificados como negros (74\%) e pardos (67\%) em comparação aos brancos (52\%) (cf. Hunter e Power, 2007, p. 5).

Muitos acadêmicos concentraram suas atenções no impacto eleitoral do programa Bolsa Família. A reeleição explicar-se-ia simplesmente pelo "bolso", já que os mais pobres estavam "significativamente melhor" em 2006 "do que quando Lula assumiu o governo em janeiro de 2003" (Idem, pp. 1, 2, 20, 24). O programa teria desempenhado um papel decisivo no crescimento da sua votação nos "municípios menos populosos e mais pobres" e entre populações que não tinham sido centros tradicionais de apoio ao PT (cf. Soares e Terron, 2008, p. 298; Zucco, 2008, pp. 33-34). Alguns, como Cesar Zucco, argumentaram que os resultados mostravam a manutenção de uma tendência longamente estabelecida das "regiōes mais pobres apoiando o candidato [presidencial] no poder" (Zucco, 2008, p. 35), expressão da dependência dos grotôes em relação ao auxílio do governo federal. 
Uma ênfase simplista nos ganhos econômicos coaduna-se facilmente com ideias bem estabelecidas sobre a falta de independência dos eleitores mais pobres do país, tradicionalmente vistos como ignorantes e atrasados pelas lentes do "iluminismo elitista" comum aos letrados de direita e de esquerda (cf. Soares, 2001, p. 238). Mal informados, facilmente iludidos e comprados, eles seriam particularmente suscetíveis à liderança carismática, à demagogia e ao clientelismo. Stéphane Monclaire criticou os estereótipos depreciativos segundo os quais metade do eleitorado com quatro anos ou menos de educação seria caracterizada por "falta de posicionamento político, alienação e irracionalidade", pois seriam incapazes de lidar com abstrações como esquerda e direita. Para Monclaire, essa abordagem conduz à desvalorização das suas decisões nas urnas à luz de normas estabelecidas por intelectuais politizados e por uma minoria educada das classes superiores, quando na verdade para os eleitores das classes populares "a vida política não está acima do dia a dia" (Monclaire, 2007, pp. 19, 26, 31) ${ }^{11}$. A chave da sua experiência com a política gira em torno da "necessária relação entre a política e o cotidiano" nas suas dimensões tanto material como simbólica (cf. Borges, 2002, p. 222; Monclaire, 2007, p. 27).

Tendo liderado greves maciças dos "peões" da indústria metalúrgica, Lula aprendeu que a batalha decisiva é pela massa de uma determinada base social, não por sua minoria politizada. Em 1991, ele destacava que o objetivo do PT deveria ser "alcançar o segmento da sociedade que ganha um salário mínimo" (Silva, 1991, p. 8) ou menos, precisamente aquele grupo que ele não conquistou na disputa presidencial de 1989. Fazendo um balanço sobre aquela primeira derrota com um grupo de intelectuais petistas, ele defendia a necessidade de "apresentar soluções que deem ao povo a chance de acreditar em nós, que lhe deem a chance de comer, de trabalhar, de viver" enquanto eles "avançam passo a passo" (Silva, 1989, pp. 29, 47).

Num país que originou a "pedagogia do oprimido" de Paulo Freire e que deu contribuiçōes importantes à Teologia da Libertação, a esquerda partidária e social brasileira avançou desde os anos de 1970 precisamente porque veio a abarcar os contornos empíricos da consciência das massas. Essa abordagem etnográfica qualitativa da política começa com o reconhecimento da integridade e da diversidade dos entendimentos, lógicas e discursos populares (cf. Monclaire, 2007, pp. 32, 35, 36-37, 43-44) ${ }^{12}$. Enquanto os estudos de comportamento eleitoral brasileiro baseiam-se muitas vezes numa "teoria dos interesses" empobrecida que deriva de uma "sociologia muscular e reducionista”, os antropólogos políticos têm insistido na fecun-
11. Em 2002, 50\% dos eleitores brasileiros não eram capazes sequer de nomear o partido do presidente Cardoso, que estava no poder havia oito anos (cf. Monclaire, 2007, p. 27).

12. Esse é o grande problema com o provocativo e muito discutido ensaio de André Singer (2009, pp. 83,99$)$. Singer vincula um lulismo esquematicamente definido a uma categoria abstrata (o subproletariado), definida por sua inserção estrutural no mercado de trabalho e, aparentemente, por sua origem geográfica no Nordeste. A partir daí, imputa a esse grupo uma consciência característica ("a manutenção da estabilidade com ação distributiva do Estado"), enquanto o associa vagamente aos camponeses da França de 1848, e Lula a Napoleão III. As teses de Singer permanecem presas à superada abordagem da nova esquerda dos anos de 1960 sobre o populismo brasileiro. Seus insights provocativos ganhariam muito de um diálogo com os estudos históricos desenvolvidos nas últimas duas décadas sobre a relação entre trabalhadores e populismo no Brasil, e também com as pesquisas que, nos últimos cinquenta anos, reexaminaram o modo como os movimentos da classe trabalhadora, incluindose aí os mais influenciados pelo marxismo, emergiram na Europa do século XIX. 
13. O ensaio introdutório a uma compilação dos discursos de Lula analisa os temas-chave abordados pelo ex-presidente, assim como suas estratégias e táticas discursivas (metáforas, repetiçōes, evocação das suas origens etc.). Ver Kamel e Elias (2009).

14. O excelente artigo de Bohn, "Social policy" (2011), desagrega o comportamento eleitoral no nível individual via pesquisas ao longo de várias eleiçōes, sugerindo os variados ritmos temporais da mudança em favor de Lula no interior das classes populares que levam a uma crescente unidade no interior dessas comunidades como um todo.

15. Um dirigente petista histórico, Dulci foi ministro-chefe da Secretaria Geral da Presidência da República sob Lula.

16. Luis Felipe Miguel (2006, pp. 122-143) oferece uma excelente discussão da ênfase acentuada sobre esse tema na campanha de televisão de Lula em 2002, enquanto reconhece que, "num país como o Brasil, onde uma parcela significativa da população não tem acesso aos bens e serviços mais básicos, o tema da 'oportunidade' pode ser entendido como uma extensão dos requisitos materiais mínimos para o exercício da cidadania" (p. 137). da função do simbólico, chamando atenção para o "papel dos elementos figurativos da linguagem" tanto para os políticos como para os eleitores: "metáforas, ironias, ambiguidades, paradoxos e hipérboles" (Barreira, 2002, pp. $167-168)^{13}$. Os pobres e os menos educados, em outras palavras, não reproduzem simplesmente disposiçôes inerentes quando vão às urnas. Seu voto também reflete lições aprendidas nas experiências políticas anteriores. Desagregando os pobres e entendendo-os como parte de comunidades locais, é possível demonstrar como modificaram sua visão sobre Lula e se aproximaram dele, passo a passo, como parte de um diálogo em progresso desde 1989 (os mais velhos, por exemplo, foram os últimos a se mover nessa direção) ${ }^{14}$. Exatamente como ocorre com os altamente educados, eles são atores de direito próprio, com suas histórias particulares, e seus pensamentos e decisões modificam-se em resposta aos acontecimentos.

Numa sociedade profundamente dividida como o Brasil, o presidente sempre tem sido um vetor dos desejos populares por melhoria de condições materiais, reconhecimento e inclusão. Em vez de confrontar um falso lulismo a um idealizado petismo, precisamos entender melhor o que um acrescenta ao outro e como ambos têm alterado a consciência do eleitorado. Colaboradores de longa data de Lula, tais como o ex-ministro Luis Dulci, não negam seu carisma pessoal, mas insistem que ele é "inextricavelmente ligado a um projeto coletivo de emancipação social" (Leblon, 2010) ${ }^{15}$. Embora isso seja verdade, não deve obscurecer o fato de que sua contribuição para promover a autoestima dos dominados apela tanto ao potencial de ação coletiva como ao desejo por mobilidade social individual, uma dimensão simbólica central ao lulismo (cf. French e Fortes, 2005) ${ }^{16}$. Após sua derrota para FHC em 1994, Lula observou:

Passar pela cabeça de uma pessoa que um torneiro mecânico tem competência para governar o Brasil não é um negócio fácil. [...] Quando estas pessoas estabelecem um preconceito contra mim, no fundo o preconceito é contra eles próprios. [...] Eles confundem capacidade política com conhecimento intelectual (apudBarreira, 2002, p. 180).

Como contestação encarnada dos preconceitos nacionais mais arraigados, o sucesso pessoal de Lula fortalece os fracos ao encorajar o orgulho por um dos "seus", contribuindo decisivamente para uma "transformação cognitiva" entre o "povão" (Monclaire, 2007, pp. 31-35). Esse senso de identificação foi mencionado pelo talentoso rapper brasileiro Mano Brown ao declarar 
seu endosso à candidatura Dilma. Brown lembrou como sua geração viu a ascensão de Lula, "um trabalhador, um nordestino, um homem do povo, tornar-se tudo que nós desejávamos que ele pudesse ser". Lula, acrescentou, foi "quase um sonho, um milagre", concluindo: ele "realizou e honrou tudo aquilo em que eu acredito desde que eu era um adolescente" (cf. Terra, 2010).

Essa política de identificação e reconhecimento é central no âmbito das massas, mas não se contrapõe à mobilização e luta populares, como muitos acreditam ao usarem o termo lulismo. O governo Lula não negligenciou o elemento participatório constitutivo do DNA petista, embora suas formas reflitam um contexto diferente. Como notou Dulci, a história de Lula está vinculada ao "trabalho árduo, diário, de construção da consciência entre as classes populares" (Leblon, 2010). Jogando a política de elite central à capacidade governamental de produzir resultados, Lula usou simultaneamente o cargo e o prestígio da presidência para promover uma série de conferências nacionais dedicadas a um amplo leque de políticas setoriais, envolvendo algo em torno de 5 milhôes de pessoas (cf. Idem). Os temas incluíram, por exemplo, direitos das mulheres $(2004,2007)$ (cf. Bohn, 2010; Sardenberg, 2004, pp. 125-129), luta pela igualdade racial $(2004,2009)$ (cf. SEPPIR, 2009, p. 31; "Primeira Conferência...", 2004) e mesmo a Primeira Conferência de Gays, Lésbicas, Bissexuais, Travestis e Transexuais (2008). Recebendo pouca atenção, esse processo sistemático de mobilização da sociedade civil foi, como notou um apoiador do PSDB, um movimento estratégico para "encorajar organizações não governamentais" e "pressionar o Congresso" (Souza, 2011, p. 81).

Essa dimensão mobilizatória e transformativa também marcou o apoio governamental à "economia solidária". Um dos exemplos simbolicamente mais poderosos são os cerca de 800 mil catadores de lixo que vivem nos ou dos principais lixões do país. O resultado foi a criação de um movimento nacional que cumpre uma grande missão ambiental por seu pioneirismo na expansão da reciclagem. Durante seus oito anos como presidente, Lula almoçou todos os dias de Natal com eles, e em 2010 levou Dilma para encontrar os 2 mil participantes vindos de todo o país num salão tomado por cartazes com slogans como "A luta é boa, a luta é dura, a luta continua" e "A rua cata, a rua canta, a rua encanta com luta". Entrevistados, os catadores celebraram seus ganhos materiais (como a construção de casas próprias) e manifestaram gratidão ("esse governo foi melhor do que os outros para os pobres. Ele deu comida e trabalho"), mas também autonomia: "Nós não pedimos as coisas. Nós reivindicamos o que é nosso por direito" (apud Lopes, 2010). 
17. A literatura sobre o Bolsa Família é vasta e crescente. Para um exame detalhado de uma perspectiva interna sobre o planejamento e a implementação, ver Fonseca (2008)

18. O texto integral da lei pode ser acessado em <http://www.planalto.gov.br/ccivil_03/_ato20042006/2004/lei/110.835.htm>.

19. Para a alocação orçamentária e suas tendências, ver Hall (2006, pp. 692-694).

20. Citado e discutido por Anderson (2011).

21. O texto completo da lei está disponível em <http://www.planalto.gov.br/ccivil_03/_ato20042006/2006/lei/l11324.htm>.

22. O texto completo da lei está disponível em <http://www. planalto.gov.br/ccivil_03/leis/ LCP/Lcp128.htm>.
Neodesenvolvimento e melhoria na qualidade de vida: os desafios do governo Rousseff

Durante o primeiro mandato de Lula, a liderança do PT conduziu a política econômica de forma cautelosa e conservadora, ao mesmo tempo em que introduzia uma ênfase redistributiva por meio de um programa que se tornaria sua marca registrada, o Bolsa Famíliaa ${ }^{17}$. Partindo da integração de programas focalizados existentes, o Bolsa Família foi se expandindo de forma eficiente até alcançar uma envergadura sem precedentes, atingindo 11,1 milhões de famílias e um total de 45 milhões de pessoas em 2006 (77\% dos elegíveis para os benefícios). Hoje, é até difícil caracterizá-lo como uma política "focalizada" de caráter "compensatório", como era comum nos pacotes neoliberais, ainda mais após a aprovação da Lei 10.835 de 2004, de iniciativa do senador Eduardo Suplicy, que estabelece o direito de todos os cidadãos brasileiros a uma Renda Mínima da Cidadania e define os programas de transferência de renda como ponto de partida para sua implementação ${ }^{18}$. Em contraste com o pagamento aos credores governamentais ou com o sistema previdenciário, mesmo com a ampliação de valor e número de beneficiários, o programa custa uma porcentagem infinitesimal do orçamento federal (2,5\%) (cf. Hunter e Power, 2007, p. 19; Amann e Baer, 2009, pp. 36-37) ${ }^{19}$, o que reforçou o bordão já anteriormente proferido por Lula de que "nada é mais barato do que cuidar dos pobres" 20.

Ao mesmo tempo, o governo implementou uma variedade de programas e iniciativas incrementais cujo impacto passou a ser sentido cada vez mais à medida que o crescimento econômico se acelerou ao longo do segundo mandato. $\mathrm{O}$ crescimento do gasto social incluiu, entre outros, crédito subsidiado para cidadãos de baixa renda, fortalecimento do apoio aos idosos, suporte ampliado para a agricultura familiar, um programa para a universalização do acesso à energia elétrica, a expansão do acesso subsidiado às universidades privadas (Prouni) e a expansão do sistema de universidades federais (Reuni). Mais decididamente, a política de aumento contínuo do salário mínimo - 67\% maior em termos reais em 2010 do que em 2003 (cf. Morais e Saad-Filho, 2011, p. 35) - teve um impacto relevante na distribuição de renda. Em 2006, o governo ampliou o estímulo à formalização do emprego doméstico, ao permitir a dedução parcial da parcela paga pelos empregadores à Previdência Social no Imposto de Renda ${ }^{21}$, e em 2008 foi estabelecida também a possibilidade de inclusão dos trabalhadores do setor informal no sistema previdenciário público ${ }^{22}$. Durante o segundo mandato, 
os investimentos em infraestrutura também se ampliaram por meio do Programa de Aceleração de Crescimento (PAC) (cf. Souza, 2011, p. 82).

O governo Lula não foi, certamente, a primeira administração desde 1989 a gerar melhoria real no bem-estar da população. Ao acabar com a hiperinflação que atingiu de forma mais dura os mais pobres, o Plano Real de 1994 - âncora econômica e eleitoral dos governos neoliberais de Cardoso - gerou benefícios efetivos, embora descontínuos (cf. Neri, 2009, pp. 233-236). Lula, muito antes de 2002, tinha reconhecido que a oposição do PT ao Plano Real tinha sido um erro. No seu governo, a melhora das condições de vida da maioria se tornou constante e acelerou consideravelmente, incluindo uma reversão dramática da tendência à crescente precarização das relações de trabalho ("flexibilização", no jargão neoliberal).

Em 2006, a despeito da fragilidade da situação econômica herdada, o modesto primeiro mandato de Lula já tinha gerado a redução da pobreza absoluta em 15\%, uma realização significativa (cf. Hunter e Power, 2007, pp. 16, 17; Barros et al., 2007). Esses resultados positivos iam contra as expectativas de muitos acadêmicos - de direita, centro ou esquerda - que duvidavam da viabilidade de reduzir desigualdades ou de implementar políticas eficazes visando garantir a subsistência de cada cidadão. Para os apoiadores das políticas neoliberais, somente "remédios amargos, mas necessários", garantiriam o bem do paciente (a economia) e a "assistência" era considerada perniciosa. Porém, muitos economistas marxistas partilhavam do postulado equivocado de que, sem reformas estruturais, "as perspectivas de melhoria material no curto prazo" não eram boas para os "cinquenta milhôes de pessoas [que] vivem atualmente abaixo da linha de pobreza" (Saad-Filho, 2003, pp. 5, 10) ${ }^{23}$.

Considerando-se as disparidades regionais, raciais, de gênero e de classe profundamente entrincheiradas ao longo da história do Brasil, os resultados positivos foram ainda mais impressionantes ao final do segundo mandato. Com 15 milhões de empregos criados, 21,5 milhões de pessoas ultrapassaram a linha de pobreza entre 2003 e 2009 , enquanto 29 milhões alcançaram o status de "baixa classe média" (o segmento "C" nas classificações mercadológicas $)^{24}$. O desemprego caiu para os níveis mais baixos já registrados, enquanto o emprego assalariado formal passou por um boom. $\mathrm{O}$ crescente poder de compra do salário mínimo - que afeta o setor formal e informal da economia, além de alguns benefícios governamentais - ampliou em 4,6\% a renda dos trabalhadores anualmente entre 2003 e 2009 (cf. Neri, 2010, p. 18). Com um governo favorável ao diálogo social e ex-sindicalistas ocupando
23. Essa opiniāo também foi partilhada pelos economistas centristas Edmund Amann e Werner Baer (2006, p. 223), que mudaram de posição em 2009. Ver Amann e Baer (2009, p. 35).

24. Uma discussão esclarecedora com estatísticas detalhadas pode ser encontrada no trabalho coordenado por Marcelo Neri (2010). Dados adicionais, vídeos e relatórios podem ser encontrados em <http://www. fgv.br/cps/ncm/>. 
posições-chave no governo, o poder de barganha dos sindicatos - a sindicalização permanece cerca de um quinto da força de trabalho formal - tem sido favorável, com $78 \%$ das negociações salariais resultando em aumentos acima da inflação, 80\% em 2009 e 89\% em 2010 (cf. Moreira, 2011).

Embora o PIB avance menos rapidamente do que na China, o crescimento no Brasil tem se associado à redução das desigualdades. De fato, a renda das classes populares está tendo um "crescimento chinês" desde 2003 (cf. Neri, 2009, pp. 229-231). Esse resultado tem legitimado o argumento da esquerda de que o consumo popular é a melhor base para o crescimento econômico ao mesmo tempo em que prova a efetividade da redistribuição guiada pelo Estado. Com seu ataque à pobreza e à desigualdade social, Lula e seu governo também mudaram o discurso público, de modo que "a redução da pobreza está agora no centro do debate político" (Zucco, 2008, p. 49). Hoje, é muito menor o número de brasileiros que, por fatalismo ou oportunismo, acreditam que "os pobres sempre estarão entre nós”, embora seja muito maior o número dos que acreditam que o Bolsa Família estará. Todos os candidatos de oposição em 2006 e 2010 declararam seu apoio ao programa e a outras medidas antipobreza, e a maioria dos brasileiros de renda mais elevada se sente bem com a redução das manifestações mais extremadas de pobreza no país.

Em maio de 2011, a presidenta Rousseff - que adotou como slogan de governo a frase "país rico é país sem pobreza" - lançou o Plano Nacional para a Erradicação da Pobreza Extrema, visando criar condições para que os 16 milhões de pessoas que ainda vivem nessa situação no país possam superála. Mesmo realizando cortes no orçamento federal, a nova administração comprometeu-se a melhorar a qualidade da educação pública, em vista do atual "bônus demográfico" marcado pela combinação entre o declínio acentuado nas taxas de natalidade e a elevação gradual na expectativa de vida. Combinando a expansão acelerada da educação superior com uma ênfase renovada no ensino técnico, o governo espera alcançar crescimento econômico sustentado, impulsionar ainda mais a mobilidade social e ajudar a criar uma sociedade mais educada, produtiva e criativa.

Dilma Rousseff começou seu mandato com uma confortável maioria na Câmara dos Deputados: 61\% dos assentos estão sob controle de partidos aliados, apenas $28 \%$ pertencem à oposição e $12 \%$ a não alinhados (cf. Pereira, 2010, p. 1). O PT voltou a ter a maior bancada de deputados (88 assentos), seguido pelo seu parceiro de coalizão, o PMDB (79). Os principais partidos de oposição (PSDB e DEM) sofreram declínios significativos, com a perda de 
um quarto das bancadas (de 131 para 96 assentos), sendo as maiores perdas sentidas pelo mais conservador deles, o DEM (de 65 para 43 parlamentares) (cf. Hunter, 2012, pp. 225-228) ${ }^{25}$. Essa redução dos parlamentares dos partidos de centro-direita confirma uma tendência visível já em 2002: a redução do número de deputados das classes mais altas e o crescimento pequeno mas contínuo daqueles oriundos das classes médias e populares (frequentemente via participação em sindicatos e Igrejas pentecostais) (cf. Rodrigues, 2009, pp. 21, 23).

Contudo a administração da presidenta Rousseff enfrenta dificuldades cruciais para implementar o seu projeto político. O Brasil mantém há muito tempo as mais altas taxas de juros reais do mundo, elevadas novamente no começo de 2011 para combater pressões inflacionárias geradas pelo crescimento do gasto público decorrente tanto das medidas anticíclicas iniciadas em 2008 como das pressóes do ano eleitoral de 2010 (incluindo aumentos para os servidores federais). Embora as altas taxas de juros no governo Lula não tenham comprometido o dinamismo do mercado brasileiro, o intenso ingresso de aplicações financeiras atraídas por esses juros elevados provoca uma sobrevalorização da moeda brasileira, que ameaça a competitividade do setor manufatureiro que sobreviveu à era neoliberal. Tanto a alta taxa de juros como o risco da inflação têm sido martelados na mídia pela oposição para justificar a demanda por cortes mais profundos no gasto público, desconsiderando a sua contribuição ao bem-sucedido combate aos efeitos da crise internacional, que evitou um quadro recessivo no país nos últimos anos.

$\mathrm{O}$ primeiro ano do governo Rousseff também assistiu à efervescência naqueles setores da força de trabalho que ainda não se beneficiaram tão significativamente das tendências redistributivas mais gerais. Protestos e greves emergiram entre trabalhadores do setor público no nível estadual (nas áreas de saúde, educação e segurança) e também entre operários empregados em grandes projetos de construção em várias partes do país, ligados ao PAC ou à preparação para a Copa do Mundo de 2014 e para as Olimpíadas de 2016.

Os funcionários públicos empregados pelos governos estaduais - professores, policiais, bombeiros e trabalhadores da saúde, entre outros - há muito recebem salários miseráveis e trabalham sob condições deploráveis. Embora os protestos atuais não estejam diretamente contra o governo federal, a ampliação e a persistência dessas lutas - às vezes fortemente respaldadas pela opinião pública - podem levar a impasses apenas passíveis de resolução com a adoção de um novo modelo de financiamento do setor público. Isso exigiria uma ruptura muito mais radical do que a inflexão observada até
25. Essa tendência aprofundou-se e complexificou-se com a criação de um novo partido de centro, integrante da base de apoio congressional ao governo Dilma, mas com laços regionais com o seu adversário José Serra, o PSD, liderado pelo prefeito de São Paulo Gilberto Kassab. 
mesmo no balizamento ortodoxo da condução macroeconômica, opção pouco provável diante da cautela exigida pelas incertezas da extensão e do grau de aprofundamento da crise internacional. As mobilizações do funcionalismo estadual, combinadas às políticas de austeridade da nova gestão presidencial, podem levar também a uma onda de greves entre os servidores federais, em face da ausência de perspectivas de novos aumentos salariais.

Já os protestos e as lutas dos trabalhadores nas grandes obras - tais como hidrelétricas e construção e reformas de estádios - colocam em foco o impacto social e ambiental dos extensos e, na maioria dos casos, necessários investimentos em infraestrutura. $\mathrm{O}$ Brasil assiste hoje à multiplicação de grandes projetos de construção civil numa escala que não era vista desde o "milagre econômico" (1968-1974) durante a ditadura militar. Os trabalhadores empregados nessas obras - assim como as comunidades e o meio ambiente impactados por elas - são tratados pelas empreiteiras responsáveis com brutalidade e desdém. Velhos padrões persistem, especialmente nas regiôes mais remotas: emprego precário, baixa remuneração, tratamento autoritário, acidentes de trabalho e descaso pela saúde e segurança, somados a grandes danos ambientais e destruição de redes sociais locais. Esses trabalhadores e comunidades muitas vezes carecem de organização, mas vivem numa sociedade em que o tratamento e o pagamento decente começaram a se estabelecer como norma. Dada a densa rede de ONGs, sindicatos, organizações de esquerda e mídia alternativa, bem como a atuação de instituições estatais como o Ministério Público e a fiscalização do Ministério do Trabalho e do Ibama, as denúncias têm se projetado nacional e internacionalmente e recebido ampla solidariedade. Parte desses conflitos pode ser solucionada com novos níveis de regulação e controle social, tal como o recentemente anunciado Compromisso Nacional para Aperfeiçoar

26. Ver <http://www.secretariageral.gov.br/compromissonacional-para-aperfeicoar-ascondicoes-de-trabalho-na-industria-da-construcao $>$. Acessado em 8 de março de 2012. as Condições de Trabalho na Indústria da Construção ${ }^{26}$; outra parte - como as controvérsias que cercam a Usina de Belo Monte ou a transposição das águas do rio São Francisco - remete a conflitos fundamentais sobre o modelo de desenvolvimento adotado pelo governo, com potencial para alienar parcelas significativas da sua base de apoio.

É importante destacar que essa nova onda de movimentos sociais e trabalhistas assim como a luta do sindicalismo pela elevação do salário mínimo em janeiro de 2011 demonstram que, ao contrário daquilo propalado por muitos analistas, os modestos mas efetivos avanços obtidos no governo Lula não serviram para desmobilizar a classe trabalhadora e a sociedade civil brasileira. É possível que essas demandas pelo aprofundamento da 
redistribuição de renda e por sua universalização marquem decisivamente o governo Rousseff. Embora a princípio compatíveis com o modelo econômico buscado pela presidenta, essas pressões, caso se tornem mais fortes e radicais, representarão um desafio para a administração, já que o caminho adotado desde Lula foi marcado por cautela e gradualismo.

Mesmo com o acúmulo de experiência no Executivo federal por parte do PT, a governabilidade ainda depende de uma coalizão política heterogênea no parlamento, composta por políticos que em grande parte buscam apenas oportunidades de enriquecimento à custa dos cofres públicos (uma das explicações para as diversas mudanças já ocorridas no gabinete ministerial). Além disso, embora a redução da vulnerabilidade externa tenha sido buscada com razoável grau de sucesso pelas gestôes petistas, a margem de ação econômica do Brasil ainda depende em grande medida do cenário internacional, e o mercado financeiro global ainda possui enorme capacidade de desestabilização. Se Lula superou todas essas contradições utilizando seu carisma e sua capacidade de negociação, os trunfos de Dilma residem mais na sua comprovada capacidade administrativa e de supervisão da execução das políticas governamentais ${ }^{27}$.

\section{Conclusão}

Ao dar a Lula três vitórias presidenciais consecutivas, os brasileiros registraram a satisfação com as escolhas que fizeram com seus votos. "As realizações do governo Lula não são revolucionárias de modo algum", notou um crítico de esquerda em março de 2011, "mas elas são suficientemente reais" para produzir impactos substantivos (cf. Morais e SaadFilho, 2011, p. 38). Os anos Lula viram dezenas de milhões de brasileiros serem integradas à plena cidadania como trabalhadores, consumidores mais ativos e pessoas cuja titularidade a direitos foi fortalecida ${ }^{28}$. A população aprendeu que a vida pode ser melhorada pelos políticos se essa realmente for a prioridade. E aprendeu também que ao menos alguns deles podem falar a sua linguagem, explicar questôes políticas e econômicas complexas de um modo que toque seus corações e que os ajude a fazer melhores escolhas nas urnas. Não importa que partidos venham a ser vitoriosos nas próximas décadas, as consequências serão sentidas por governantes e governados.

Um impacto extremamente relevante e com frequência subestimado do sucesso de Lula é o fortalecimento da autoestima da maioria popular
27. Gilberto Calcagnotto (2011, pp. 169-174) menciona o papel de Dilma no gabinete de Lula e propōe uma interessante discussão de como ela construiu o seu próprio gabinete.

28. Essa crescente autoconfiança é um dos temas centrais do excelente livro recente de James Holston sobre as classes populares de São Paulo desde os anos de 1970. Ver Holston (2008). 
29. As nomeaçōes políticas para os cargos mais altos durante o primeiro mandato de Lula demonstraram substancial continuidade com o governo Cardoso no seu perfil demográfico, ocupacional e educacional (três quartos ou mais eram homens, brancos $\mathrm{e}$ com educação universitária). A distinção das nomeaçōes do PT reside na ampliação daqueles cuja atuação política se iniciou no movimento sindical ou na oposição clandestina à ditadura militar. Ver D’Araújo (2007). $\mathrm{O}$ influxo de indivíduos menos vinculados à elite é mais sentido nos níveis inferiores da hierarquia dos ministérios, e é muito mais alto nos níveis dos estados e dos municípios onde o PT chegou ao poder.

30. Partidos de esquerda (PT, PDT, PSB, PCdoB, PSOL) respondiam por $56 \%$ do total.

31. A frase captura a "descontinuidade dentro da continuidade", com a continuidade "predominando no reino da política macroeconômica” enquanto a descontinuidade é encontrada na luta contra assimetrias internacionais, nos esforços para aprofundar a democracia e nos passos para reconstruir a capacidade do Estado e levar a cabo a redistribuição enquanto avança o desenvolvimento nacional.

32. Ver, por exemplo, Ferreira e Fortes (2008). ao desafiar preconceitos internalizados e comportamentos autoinibidores cultivados por uma sociedade autoritária com base na dominação e no paternalismo. Entretanto, os avanços alcançados, embora significativos e substanciais, ficam muito aquém do que é necessário para resolver as "mazelas sociais" denunciadas com tanta eloquência por André Rebouças. Embora o país tenha feito história ao eleger uma presidenta, ainda ocupa a $142^{\text {a }}$ pior colocação mundial quanto ao percentual de mulheres em cargos legislativos nacionais (apenas 9\% contra uma média mundial de 18\%) (cf. Bittencourt, 2009, pp. 84-89). E a ampliação das oportunidades para indivíduos das classes populares e para a população afrodescendente não trará frutos até o momento em que os atuais estudantes universitários de primeira geração ascendam nas estruturas econômicas, políticas e administrativas ${ }^{29}$. Um avanço simbólico importante, embora modesto, foi obtido em 2010: a porcentagem dos autoidentificados como negros dobrou na Câmara dos Deputados, para 43 (8,5\% dos assentos num país cujo último censo registrou uma maioria populacional de afrodescendentes) (cf. União dos Negros pela Igualdade, 2011) ${ }^{30}$.

Depois de administrar uma nação, o projeto de Lula, do PT e da esquerda brasileira é agora mais claro. No nível doméstico: implementar um projeto nacional de desenvolvimento inclusivo e participativo. Internacionalmente: consolidar o protagonismo do país - numa base nova e soberana - diante de uma instável economia global capitalista ainda governada de forma injusta, desigual e predatória. Hoje, o "neoliberalismo não é mais o único jogo em curso" (Burdick et al., 2009, pp. 1230), embora a emergente era pós-neoliberal não deva ser entendida como uma completa superação, e sim como "uma busca por agendas progressistas emergindo" das múltiplas contradições do neoliberalismo. Como sugerem Macdonald e Ruckert (2009, pp. 6-7), "as políticas neoliberais perderam a sua dominância, mas ainda não estão aniquiladas" e as alternativas emergentes contêm, elas próprias, "fragmentos do modelo neoliberal anterior" ${ }^{\prime \prime}$.

A construção de "um novo mundo" - tal como defendido no slogan do Fórum Social Mundial - avançou mais rapidamente no Brasil do que em outros lugares, como resultado da unificação da geração de ativistas de 1978-1980 - ancorada nas classes populares e trabalhadoras - com a geração radical de 1968, de estudantes, freiras e padres, da qual Dilma Rousseff fez parte ${ }^{32}$. Integrante de um grupo marxista dedicado à luta clandestina contra a ditadura militar nos anos de 1960, Dilma foi acusa- 
da de "ensinar teoria revolucionária a trabalhadores" (Folha de S. Paulo, 2010), foi presa, torturada e passou vários anos na prisão, experiências que a diferenciaram da maioria de seus pares de classe média. "Por causa do que passei", ela contou ao jornal oposicionista Folha de S. Paulo, "eu vim a entender muitas coisas [incluindo] o valor da democracia". Esquivando-se de diversas abordagens que buscavam constrangê-la a se desculpar pelas táticas militantes da sua juventude, Rousseff declarou: "Eu não tenho a mesma cabeça hoje que eu tinha então. Seria estranho se eu tivesse. Seria até mesmo patológico. [Mas] não, eu não mudei de lado. Isso é motivo de orgulho para mim. Eu mudei apenas os meus métodos e a minha visão" (Odilla, 2009).

\section{Referências Bibliográficas}

AmAnn, Edmund \& BAER, Werner. (2006), "Economic orthodoxy versus social development? The dilemmas facing Brazil's labour government". Oxford Development Studies, 34 (2): 219-241.

. (2009), "The macroeconomic record of the Lula administration, the roots of Brazil's inequality, and attempts to overcome them”. In: BAER, Werner \& LOVE, Joseph (orgs.). Brazil under Lula: economy, politics, and society under the workerpresident. New York, Palgrave Macmillan.

AmARAL, Leandro. (2010), “ 'Os metalúrgicos do ABC não vão se livrar de mim', avisa Lula”. Repórter Diário, $1^{\circ}$ de junho.

Anderson, Perry. (2011), "Lula's Brazil". London Review of Books, 33 (7): 3-12.

BAER, Werner \& LOve, Joseph. (2009), Brazil under Lula: economy, politics, and society under the worker-president. New York, Palgrave Macmillan.

BARreira, Irlys Alencar F. (2002), "Um operário presidente? Ideologia e condição de classe no universo da representação política”. In: Heredia, Beatriz Maria Alásia de, Teixeira, Carla Costa \& Barreira, Irlys Alencar F. (orgs.). Como se fazem eleições no Brasil. Rio de Janeiro, Relume Dumará.

BARros, Ricardo Paes de et al. (2007), "A importância da queda recente das desigualdades na redução da pobreza”. Textos para Discussão 1256. Brasília, Instituto de Pesquisa Econômica Aplicada (IPEA).

Bethell, Leslie \& Nicolau, Jairo. (2008), "Politics in Brazil, 1985-2002". In: BeTHELL, Leslie (org.). Brazil since 1930. New York, Cambridge University Press.

Bittencourt, Ana. (2009), "Mulheres na política: entraves e conquistas". Democracia Viva, 41: 84-89. 
Bohn, Simone R. (2010), "Feminismo estatal sob a presidência Lula: o caso da Secretaria de Políticas para as Mulheres". Revista Debates, 4 (2): 81-106.

(2011), "Social policy and the vote in Brazil: Bolsa Família and the shifts in Lula's electoral base". Latin American Research Review, 46 (1): 54-79.

Borges, Antoniádia Monteiro. (2002), "Tanto azul, quanto vermelho”. In: HerediA, Beatriz Maria Alásia de, TeIXeIrA, Carla Costa \& Barreira, Irlys Alencar F. (orgs.). Como se fazem eleiçôes no Brasil. Rio de Janeiro, Relume Dumará.

Burdick, John, Oxhorn, Philip \& Roberts, Kenneth M. (orgs.). (2009), Beyond neoliberalism in Latin America? Societies and politics at the crossroads. New York, Palgrave Macmillan.

Calcagnotto, Gilberto. (2011), "Dilma e o problema de seguir mudando o imutável: novas perspectivas para a reforma política no Brasil?”. Iberoamericana, XI (41): 169-174.

CÉSAR, Benedito Tadeu. (2002), PT, a contemporaneidade possivel: base social e projeto político (1980-1991). Porto Alegre, Editora da Universidade/Instituto de Filosofia e Ciências Humanas/Ufrgs.

D’Araújo, Maria Celina Soares (org.). (2007), O governo Lula: contornos sociais e políticos da elite do poder. Rio de Janeiro, CPDOC.

Declaración final. (2008), Xiv Encuentro del Foro de São Paulo, Montevideo, Uruguay, 22-25 de maio.

. (2009), xv Encuentro del Foro de São Paulo, Ciudad de México, 20-23 de agosto.

EKINS, Zachary. (2000), "Quem iria votar? Conhecendo as consequências do voto obrigatório no Brasil”. Opiniāo Pública, 6 (1): 109-136.

Ferreira, Marieta de Moraes \& Fortes, Alexandre. (2008), Muitos caminhos, uma estrela: memórias de militantes do PT. São Paulo, Editora Fundação Perseu Abramo.

FOLHA DE S. PAULO. (2010), "Na ditadura, Dilma deu aulas de política a trabalhadores". Folha de S. Paulo, 28 de novembro. Disponível em <http://www1.folha.uol.com. br/poder/837387-na-ditadura-dilma-deu-aulas-de-politica-a-trabalhadores.shtml>.

FonseCA, Ana. (2008), "Transferência de renda: continuidades e rupturas na experiência do programa Bolsa Família”. Comunicação apresentada à conferência Nurturing Hope, Deepening Democracy, and Combating Inequalities: An Assessment of Lula's Presidency. Duke University, 27-28 de maio.

FORTES, Alexandre. (2009), "In search of a post-neoliberal paradigm: the Brazilian left and Lula's government". International Labor and Working-Class History, 75: 109-125.

French, John D. (2009), “Understanding the politics of Latin America’s plural lefts (Chávez/Lula): social democracy, populism, and convergence on the path to a post-neoliberal world". Third World Quarterly, 30 (2): 349-370. 
(2010), "The professor and the worker: using Brazil to better understand Latin America’s plural left”. In: Moraña, Mabel \& Gustafson, Bret (orgs.). Rethinking intellectuals in Latin America. Frankfurt/Madrid, Vervuert/Iberoamericana, pp. 91-113.

FrenCH, Joseph \& ForTes, Alexandre. (2005), "Another world is possible: the rise of the Brazilian workers' party and the prospects for Lula's government". Labor, 2 (3): 13-31.

(2012), "Nurturing hope, deepening democracy, and combating inequalities in Brazil: Lula, the workers' party, and Dilma Rousseff's 2010 election as president". Labor, 9 (1): 7-28.

GuimARĀes, Juarez. (2008), “O PT, o governo Lula e a cultura política brasileira”. Comunicação inédita à Conferência de Pesquisa Internacional sobre o Governo Lula. Duke University, 27-28 de maio.

Hall, Anthony. (2006), "From Fome Zero to Bolsa Família: social policies and poverty alleviation under Lula”. Journal of Latin American Studies, 38: 689-709.

Holston, James. (2008), Insurgent citizenship: disjunctions of democracy and modernity in Brazil. Princeton, Princeton University Press.

Hunter, Wendy. (2008), "Partido dos Trabalhadores: still a party of the left?". In: Kingstone, Peter R. \& Power, Timothy J. (orgs.). Democratic Brazil revisited. Pittsburgh, University of Pittsburgh Press.

(2012), “The 2010 elections in Brazil”. Electoral Studies, 31 (1): 225-228, mar.

Hunter, Wendy \& Power, Timothy J. (2007), "Rewarding Lula: executive power, social policy, and the Brazilian elections of 2006". Latin American Politics and Society, 49 (1): 1-30.

JiNKINGS, Daniella. (2011), "Plano para erradicar pobreza extrema incluirá 1,5 milhão de famílias, diz ministra”. Carta Capital. Disponível em <http://www.cartacapital. com.br/politica/plano-para-erradicar-pobreza-extrema-incluira-15-milhao-defamilias-diz-ministra>.

Kamel, Ali \& Elias, Rodrigo. (2009), Dicionário Lula: um presidente exposto por suas palavras. Rio de Janeiro, Nova Fronteira.

Kingstone, Peter R. \& Ponce, Aldo F. (2010), "From Cardoso to Lula”. In: Weyland, Kurt et al. (orgs.). Leftist governments in Latin America. Cambridge, Cambridge University Press.

LACERDA, Laura. (2010), “'Lula está acima do bem e do mal', afirma Serra”. Estado de S. Paulo, 14 de maio.

Leblon, Saul. (2010), "A elite chama de populismo a democratização das decisōes - Entrevista com Luiz Dulci”. Agência Carta Maior, 11 de novembro. Disponível em <http:// www.cartamaior.com.br/templates/postMostrar.cfm?blog_id=6\&post_id=612>. 
Lopes, José Henrique. (2010), "Catadores se despedem de Lula e agradecem por vida melhor: trabalhadores celebram avanços dos últimos oito anos e esperam continuidade com Dilma”. R7 Notícias, 24 de dezembro. Disponível em <http:// noticias.r7.com/brasil/noticias/catadores-se-despedem-de-lula-e-agradecem-porvida-melhor-20101224.html>.

MacDonald, Laura \& Ruckert, Anne (orgs.). (2009), Post-neoliberalism in the Americas. New York, Palgrave Macmillan.

Miguel, Luis Felipe. (2006), "From equality to opportunity: transformations in the discourse of the workers' party in the 2002 elections". Latin American Perspectives, 33 (4): 122-143.

Monclaire, Stéphane. (2007), "Lula II, un vote de reconnaissance". Lusotopie, XIV (1): 3-70.

MoraIs, Lecio \& SAAD-FILHO, Alfredo. (2011), "Brazil beyond Lula: forging ahead or pausing for breath?”. Latin American Perspectives, 38 (2): 31-44.

Moreira, Marli. (2011), "Ganhos salariais acima da inflação tiveram recorde em 2010, segundo o Dieese”. Agência Brasil. Disponível em <http://agenciabrasil.ebc.com. br/noticia/2011-03-17/ganhos-salariais-acima-da-inflacao-tiveram-recorde-em2010-segundo-dieese>.

Neri, Marcelo. (2009), "Income policies, income distribution, and the distribution of opportunities in Brazil”. In: Brainard, Lael \& Martinez-Diaz, Leonardo (orgs.). Brazil as an economic superpower? Understanding Brazil's changing role in the global economy. Washington, D.C., Brookings Institution Press.

. (2010), A nova classe média: o lado brilhante dos pobres. Rio de Janeiro, Editora da Fundação Getulio Vargas.

Odilla, Fernanda. (2009), "Dilma diz não ter a mesma cabeça da época em que era guerilheira". Folha de S. Paulo, 5 de abril.

Pereira, Carlos. (2010), "Brazil's executive-legislative relations under the Dilma coalition government". Washington, Brookings Institution.

Pimentel, Fernando. (2004), “O paradoxo brasileiro”. Teoria e Debate, 56, dez.-jan. POwer, Timothy J. \& Zucco Jr., Cesar. (2009), "Estimating ideology of Brazilian legislative parties, 1990-2005: a research communication”. Latin American Research Review, 44 (1): 218-246.

RAÇA BRASIl. (2004), "Primeira Conferência Nacional da Promoção da Igualdade Racial, realizada em Brasília por SEPPIR, reuniu negros, índios, judeus e ciganos para debater e festejar”. Revista Raça Brasil, 89.

Rodrigues, Leôncio Martins. (2009), Mudanças na classe política brasileira. São Paulo, Centro Edelstein de Pesquisas Sociais.

SAAD-FILHO, Alfredo. (2003), "New dawn or false start in Brazil? The political economy of Lula's election”. Historical Materialism, 11 (1): 3-21. 
SAmuels, David. (2004), "From socialism to social democracy: party organization and the transformation of the workers' party in Brazil". Comparative Political Studies, 37 (9): 999-1024. . (2006), "Sources of mass partisanship in Brazil". Latin American Politics and Society, 48 (2): 1-27.

Santos, Sydney M. G. dos. (1985), André Rebouças e seu tempo. Rio de Janeiro, Vozes. SARDENBERG, Cecilia Maria Bacellar. (2004), "With a little help from our friends: 'global' incentives and 'local' challenges to feminist politics in Brazil'. IDS Bulletin, 35 (4): 125-129.

Seppir (Secretaria Especial de Política de Promoção da Igualdade Racial). (2009), Subsidios à II Conapir (Conferência Nacional de Promoção da Igualdade Racial). Brasília, SEPPIR/CNPIR.

Silva, Luiz Inácio Lula da. (1989), Visões da transição. São Paulo, CEDEC, vol. 2. (1991), "Entrevista: Lula - Mãos à obra”. Teoria e Debate, 13. . (2007), "Discurso do presidente da República Luiz Inácio Lula da Silva na segunda Conferência Nacional de Políticas para as Mulheres”. Secretaria de Políticas para as Mulheres da Presidência da República Federativa do Brasil. Disponpível em <http://www.sepm.gov.br/pnpm/discurso-pr-iicnpm.pdf>.

Silva, Pedro Barros, Braga, José de Souza \& Costa, Vera Cabral. (2010), "Lula’s administration at a crossroads". In: WeYLAND, Kurt et al. (orgs.). Leftist governments in Latin America: successes and shortcomings. Cambridge, Cambridge University Press. Singer, André. (2009), "Raízes sociais e ideológicas do lulismo". Novos Estudos Cebrap, 85: 83-102.

. (2010), "A segunda alma do Partido dos Trabalhadores". Novos Estudos Cebrap, 88: 89-111.

SoAres, Gláucio Ary Dillon. (2001), A democracia interrompida. Rio de Janeiro, Editora da Fundação Getulio Vargas.

SoAres, Gláucio Ary Dillon \& Terron, Sonia Luiza. (2008), "Dois Lulas: a geografia eleitoral da reeleição (explorando conceitos, métodos e técnicas de análise geoespacial)”. Opiniāo Pública, 14 (1): 269-301.

SouzA, Amaury de. (2011), "The politics of personality in Brazil". Journal of Democracy, 22 (2): 75-88.

TAPPER, Jack. (2009), “The significance of president Obama praising Lula's 'good looks' ". Political Punch. Washington, ABC News.

Terra. (2010), "Mano Brown declara apoio a Dilma: 'povo não quer ser gado”. Terra, 18 de outubro. Disponível em <http://noticias.terra.com.br/eleicoes/2010/ noticias/0,oi4739900-ei15315,00-Mano+Brown+declara+apoio+a+Dilma+povo+ nao+quer+ser+gado.html>. 
Uniâo de negros pela igualdade. (2011), Balanço eleitoral do voto étnico e presença dos negros no Parlamento. Belo Horizonte, Unegro/UfoP.

Zucco, Cesar. (2008), “The President's 'New' Constituency: Lula and the pragmatic vote in Brazil's 2006 presidential elections". Journal of Latin American Studies, 40 (1): 29-49.

\section{Resumo}

A "Era Lula", as eleições presidenciais de 2010 e os desafios do pós-neoliberalismo $\mathrm{O}$ artigo explora o impressionante sucesso do Partido dos Trabalhadores (PT) e do seu líder, o ex-sindicalista Lula, ao conquistar uma terceira vitória presidencial consecutiva com a eleição de Dilma Rousseff em 2010. Em perspectiva histórica, ele examina os modos como o governo Lula representou uma ruptura com o passado, resumindo suas realizaçôes substantivas em termos de distribuição de renda e criação de oportunidades. Debatendo a relação entre o petismo e o lulismo, o trabalho oferece evidências de que Lula e o PT mantiveram seu éthos fundante de fortalecimento à autoestima popular e promoção da cidadania participativa, embora sob novas circunstâncias. O texto termina com um diagnóstico dos desafios do governo Dilma Rousseff à luz da situação da economia internacional, das novas lutas trabalhistas emergentes no país e das limitaçôes impostas pelo sistema político brasileiro.

Palavras-chave: Partido dos Trabalhadores; Lula; Dilma Rousseff; Eleiçōes presidenciais; Pós-neoliberalismo.

Texto recebido em 17/2/2012 e aprovado em 27/3/2012.

Alexandre Fortes é professor da Universidade Federal Rural do Rio de Janeiro, autor de Nós do quarto distrito: a classe trabalhadora porto-alegrense e a era Vargas (Garamond, 2004) e organizador de História e perspectivas da esquerda (Argos/ Fundação Perseu Abramo, 2005). E-mail: <alexfortes@globo.com>. John French é professor da Duke University, Estados Unidos, e autor de $O A B C$ dos operários: conflitos e alianças de classe em São Paulo 1900-1950 (Hucitec, 1995) e de Afogados em leis: A CLT e a cultura politica dos trabalhadores brasileiros (Fundação Perseu Abramo, 2001). E-mail: $<$ jdfrench@duke.edu>.

\section{Abstract}

The "Lula Era", the 2010 presidential elections and the challenges of post-neoliberalism The article explores the stunning success of the Brazilian Workers Party (РT) and its leader, Lula, former trade unionist, in winning a third consecutive presidential victory, with the election of Dilma Rousseff in 2010. In historical perspective, it examines the ways in which Lula's government (2002-2010) represented a break with the past while summarizing its substantive achievements in redistributing wealth and opportunity. Focusing on the tension between a historic party-centric petismo (declared partisan party support) and the broader personal popularity of its leader (lulismo), it offers evidence that Lula and the PT have retained their foundational ethos of enhancing popular self-esteem while fostering citizen participation and civil society mobilization, albeit under new conditions. It concludes with a diagnosis of Dilma Rousseff government's challenges in light of the international economic scenario, domestic labor mobilizations, and the constraints of the Brazilian political system.

Keywords: Workers' Party; Lula; Dilma Rousseff; Presidential elections; Postneoliberalism. 